\title{
The Effect Of Brand Image, Quality Products And Price On Samsung Handphone Decision Purchase
}

\author{
Della Nuril $\mathrm{M}^{1}$, Yuniorita Indah Handayyani ${ }^{2}$ \\ Student STIE Mandala Jember ${ }^{1}$, Lecturer, STIE Mandala Jember ${ }^{2}$ \\ Email: yuniorita@stie-mandala.ac.id ${ }^{2}$
}

\begin{abstract}
This study aims to determine the effect of Brand Image either together or partially or to know the variables that affect consumer purchasing decisions. Independent variables used in this study are brand image (X1), Product Quality (X2) and Price (X3) while the dependent variable is Purchase Decision (Y). The research method used in this research is quantitative research method by using sample of 50 respondents of STIE Mandala Jember Students. Data analysis method used in this research is descriptive analysis method and multiple linear regression analysis. Data processing is done by using computer software SPSS 20 for windows.
\end{abstract}

Keywords: Brand Image, Product Quality, Price and Purchase Decision

\section{INTRODUCTION}

The increasing mobility of Indonesian society, as well as current technological advances have resulted in the need for communication and information changing from being a secondary need to a primary need in society. Cellular phones or cellphones are one of the technological tools that are slowly changing and socializing media for the people in Indonesia, so that people are always informed and easy to communicate.

Samsung is one of the pioneers of cellular telephones or mobile phones in Indonesia. After nearly two decades of studying the needs and wants of consumers in Indonesia in particular, Samsung has turned into a giant mobile phone in Indonesia.

The large number of smartphones entering Indonesia provides a wide choice of brands, product quality, and prices for Indonesian consumers. The brand identifies the source or manufacturer of the product and supports consumers to hold responsibility for its performance 
from a particular manufacturer or distributor. A successful brand is a great product or service, backed by careful planning, a large number of long-term commitments, and creatively designed and executed marketing. A strong brand generates very high consumer loyalty.

The existence of Samsung mobile phones in enlivening the mobile phone market in Indonesia, since the late 1990s which is known as the entry-level cellphone until now as the king of cellular phones in the world, creates an effective and positive branding among consumers of Samsung mobile products.

Nurkhayati (2012) explains that before making a purchase, generally consumers will search for information on products that suit their needs. Information on a product, the consumer will evaluate and compare the product with other products, after the results of the thought (evaluation and comparison) give the result that the product purchased is in accordance with or in other words the consumer is interested in a certain product, then the consumer will actualize his thinking. by making a purchase for the product.

From the description of the above problems, the authors are very interested in conducting research on consumer buying interest in their decision to purchase Samsung OS Android phones. The problem of this research is whether brand image, product quality and price will influence buying decisions.

\section{RESEARCH METHODS}

\section{Object of research}

This research was conducted at the STIE MANDALA JEMBER campus, which is addressed at Jalan Sumatra No. 118-120 Jember.

\section{Population and Research Sample}

The population used in this study were students of STIE MANDALA JEMBER who had a Samsung mobile phone. This research took place from May to June 2016. The sampling technique used was probability sampling, in which all individuals in the population were given the same opportunity to become sample members.

\section{Operational Definition of Variables}

Operationally the researchers took measurement benchmarks for each variable, including: 
Brand image can be measured by several indicators such as brand recognition, brand popularity, and trusted brands.

2. Product Quality (X2)

Product quality can be measured by several indicators such as product design, product reliability, and features.

\section{Price (X3)}

Prices can be measured by several indicators such as competitive prices for similar products, price compatibility with product quality, affordability of product prices to consumers.

\section{Purchase Decision (Y)}

Purchasing decisions can be measured by several indicators such as choosing a product because of the price offered, making a choice on the best product, and the quality of the product offered.

\section{Data analysis method}

\section{A. Validity Test}

The criteria applied to measure whether a data is valid or not is if r-count (correlation coefficient) is greater than r-table (critical value) it can be said to be valid. In addition, if the significant value $<0.05$, the instrument can be said to be valid (Ghozali, 2013)

$$
r=\frac{\mathrm{n} \Sigma \mathrm{xy}-(\Sigma \mathrm{x})(\Sigma \mathrm{y})}{\sqrt{\left(\mathrm{N} \Sigma \mathrm{x}^{2}-(\Sigma \mathrm{x})^{2}\right)\left(\mathrm{N} \Sigma \mathrm{y}^{2}-(\Sigma \mathrm{y})^{2}\right.}}
$$

\section{Caption :}

$r=$ correlation coefficient of independent variable and dependent variable

$\mathrm{n}=$ number of samples

$\mathrm{x}=$ Score of each item

$y=$ Total variable score

B. Reliability Test 
An instrument is said to be reliable if it has a positive alpha value and is greater than 0.6 where the greater the alpha value, the more reliable the measuring tool used (Ghozali, 2013). In this study, the calculation of reliability uses the Alpha formula:

$\mathrm{r} 11=\left(\frac{k}{k-1}\right)\left(1-\frac{\sum \sigma \mathrm{b}^{2}}{\sigma \tau^{2}}\right)$

Caption :

r11: Instrument reliability

$\mathrm{k}$ : Number of questions

$\sigma b^{2}$ : Number of grain variants

$\sigma \tau^{2}:$ The sum of the total variance

C. Multiple Linear Regression Analysis

The use of this analysis tool is to determine the form of the relationship between the independent variable $(\mathrm{X})$ and the dependent variable $(\mathrm{Y})$. Here is a multiple linear regression formula:

$$
\mathrm{Y}=\alpha+\beta 1 \mathrm{X} 1+\beta 2 \mathrm{X} 2+\beta 3 \mathrm{X} 3+\varepsilon
$$

Caption :

$\mathrm{Y}=$ consumer decision

$\alpha=$ Intercept

$\beta 1 \beta 2 \beta 3 \beta 4 \beta 5 \beta 6=$ regression coefficient

$\varepsilon=$ item error, $\mathrm{X} 1=$ brand, $\mathrm{X} 2=$ price, $\mathrm{X} 3$ = product quality

\section{Partial Test ( $\mathrm{t}$ test)}

The $t$ test was conducted to test the regression coefficient partially from independent variable. The calculated t value can be found with the formula:

thitung $=\frac{r \sqrt{n-2}}{\sqrt{a-r^{2}}}$

\section{E. Simultaneous Test (Test F)}

Testing is done using the F test, namely by comparing the F table with the F count contained in the Analysis of Variance table. The calculated F value can be found by: 
rumus $=\frac{R^{2} / k}{\left(1-R^{2}\right) /(n-k-1)}$

Caption :

$R=$ coefficient of determination

$\mathrm{n}=$ number of samples

$\mathrm{k}=$ many independent variables.

\section{RESULT AND DISCUSSION}

1. Validity and Reliability Test

a. Vailidity Test

From the results of instrument testing, the results show that statement items 1 to 12 are declared valid because each statement item has a significance level of less than 0.05.

b. Reliability Test

Instrument testing on 50 respondents with 12 question items, the results obtained by calculating with Cronbach's Alpha are equal to 0.883 .

2. Multiple Linear Regression Analysis

The regression equation is obtained from the following table.

Table 1. Result of Analysis

Coefficients

\begin{tabular}{|c|c|c|c|c|c|c|c|}
\hline \multirow[t]{2}{*}{ Model } & \multicolumn{2}{|c|}{$\begin{array}{l}\text { Unstandardized } \\
\text { Coefficients }\end{array}$} & \multirow{2}{*}{\begin{tabular}{|c|}
$\begin{array}{c}\text { Standardized } \\
\text { Coefficients }\end{array}$ \\
Beta
\end{tabular}} & \multirow[t]{2}{*}{$\mathrm{t}$} & \multirow[t]{2}{*}{ Sig. } & \multicolumn{2}{|c|}{$\begin{array}{c}95,0 \% \text { Confidence } \\
\text { Interval for B }\end{array}$} \\
\hline & B & Std. Error & & & & $\begin{array}{l}\text { Lower } \\
\text { Bound }\end{array}$ & $\begin{array}{l}\text { Upper } \\
\text { Bound }\end{array}$ \\
\hline (Constant) & ,651 & 2,224 & & 293 & ,771 & $-3,825$ & 5,127 \\
\hline $\mathrm{X} 1$ &, 248 & , 154 &, 249 & 1,611 & ,114 &,- 062 & ,559 \\
\hline$\times 2$ & ,491 & , 189 &, 344 & 2,594 & ,013 & , 110 & ,871 \\
\hline X3 & ,210 & , 182 & , 177 & 1,155 & ,254 &,- 156 &, 575 \\
\hline
\end{tabular}

Source : Output SPSS, 2018 


$$
\mathrm{Y}=0,651+0,248 \mathrm{X} 1+0,491 \mathrm{X} 2+0,210 \mathrm{X} 3+\varepsilon
$$

This multiple linear regression equation can be seen from the influence of Brand Image (X1), Product Quality (X2), and Price (X3) on Purchasing Decisions (Y) for Active Students 2015. The explanation of the results of the multiple linear regression equation above is as follows :

a. The value of the constant (a) shows a positive value which means that there is a positive influence on the Purchase Decision (Y) in 2015 Active Students if Brand Image (X1), Product Quality (X2), and Price (X3) is fixed or constant.

b. Brand Image (X1) has a positive value or positive influence on purchasing decisions (Y).

c. Product Quality (X2) has a positive value or positive influence on Purchasing Decisions (Y).

d. Price (X3) has a positive value or a positive influence on Purchase decision (Y).

\section{Test}

Testing the regression coefficient value of each independent variable can be done in two ways, namely, by comparing the arithmetic statistics and table statistics,

a. If tcount <ttable, it means that $\mathrm{Ho}$ is accepted and $\mathrm{Ha}$ is rejected, so the variables of Brand Image (X1), Product Quality (X2), and Price (X3) do not have a significant effect on Purchasing Decisions (Y).

2. If tcount $>$ ttable, it means that Ho is rejected and Ha is accepted, so the Brand Image (X1), Product Quality (X2), and Price (X3) variables have a significant effect on Purchasing Decisions (Y).

Based on the table above, it can be explained as follows:

\section{X1 (Brand Image)}

The result of tcount for the brand image variable (X1) is known to be 1.611 , so it can be seen that $\mathrm{X} 1$ has an effect on purchasing decisions. By using the $\mathrm{t}$ table used a significant level of 95\% obtained t table 2.00958 (Appendix 7) so that tcount <ttable is $1.611<2.00958$ means this means that partially the brand image variable has no significant effect on purchasing decisions for Samsung cellphones.

2. X2 (Product Quality) 
The result of tcount for the variable Product Quality (X2) is known to be 2.594. By using the t-table used a significant level of $95 \%$ obtained t table 2.00958 (Appendix 7) so that tcount> ttable is 2.594> 2.00958, this means that partially the Product Quality variable has a significant effect on purchasing decisions for Samsung cellphones.

3. X3 (Price)

The result of tcount for the variable Price (X3) is known to be 1.155. By using t table used a significant level of $95 \%$ obtained $t$ table 2.00958) so that $\mathrm{t}$ count $<\mathrm{t}$ table is $1.155<2.00958$ means this means that partially the price variable has no significant effect on purchasing decisions for Samsung cellphones.

The results of testing the effect of the price variable (X3) partially on Purchasing Decisions with the statistical t test can be seen in the figure as it is known that tcount of 1.155 is in the area H0 is accepted, which states that Price (X3) as an independent variable has no significant effect on HP Purchase Decisions. Samsung. Based on the explanation above, it can be concluded that X3 (Price) partially has no significant effect on Purchasing Decision (Y).

\section{Test F}

The results of calculations from data processing with SPSS version 20.0 show that the Fcount value is 10.535 (attachment 5). By using the F table (attachment 6) at an error rate of 0.05 and a significant level of $95 \%$, it is found Ftable $=(\mathrm{df} 1 / \mathrm{df} 2=3 / 46=2.81)$ so that it can be seen that the value of Fcount $>$ Ftable is $10.535>2.81$. So it can be concluded that Ha is accepted and Ho is rejected as in the following table:

In the analysis section of the research results that need to be stated is proof whether the results of the analysis of the data collected can prove the hypothesis proposed.

Table 2. Recapitulation of the Simultaneous Influence of Independent Variables

\begin{tabular}{|l|l|l|l|}
\hline Variabel & Label & Fhitung & Ftabel \\
\hline X1 & Citra Merek & 10,535 & 2,81 \\
\hline X2 & Kualitas Produk & 10,535 & 2,81 \\
\hline X3 & Harga & 10,535 & 2,81 \\
\hline
\end{tabular}


In general, this research shows satisfactory results. This is indicated by the number of high satisfaction responses from respondents to each research variable and from these results have a significant effect on customer satisfaction. This is because the brand image and product quality provided and the appropriate price will create satisfaction in consumers. The satisfaction that is formed will be the basis for further and providing recommendations to others.

\section{Influence of Brand Image on Purchasing Decisions}

The results showed that the brand image variable had an influence on purchasing decisions. These results provide empirical evidence that a brand image that gives a brand impression to its users that always carries a level of self-confidence will provide individual satisfaction for consumers.

\section{Influence of product quality on purchasing decisions}

The results showed that the variable product quality had a positive influence on purchasing decisions. These results provide empirical evidence that the quality of the product from the product provider is indicated by the durability and motive of the product as expected, and the quality of the raw materials used has guaranteed quality will determine consumer satisfaction. 3. The effect of price on purchasing decisions

The results showed that the price variable had a positive influence on purchasing decisions. These results provide empirical evidence that prices from product providers, indicated by affordability, will provide satisfaction to customers.

\section{CONCLUSION}

Based on data analysis, it is concluded that partially the brand image (X1) and price (X3) variables have no significant effect on purchase decisions (Y), while product quality (X2) has a significant effect on purchasing decisions. These results are consistent with the results of research by Goenandhi and Andrianto (2011). However, the overall variable brand image (X1), product quality (X2) and price (X3) together have a significant effect on purchasing decisions (Y). 


\section{IMPLICATIONS}

Based on the research results, the product quality has a significant effect so that companies need to maintain the quality or improve the quality of their products. The quality of good Samsung HP products must be maintained

\section{REFERENCES}

Aaker, David. A. 1996. Building Strong Brands. New York: The Free Press.

Afandy, U. 2008. Analisis Pengaruh Ekuitas Merek, Harga, dan Lingkungan Sosial Terhadap Keputusan Pembelian Kartu IM3. Jakarta: UIN Jakarta.

Andrianto Idris (2013), "Pengaruh Kualitas Produk, Citra Merek, Harga dan Promosi terhadap Keputusan Pembelian Mobil Jenis MPV Merek Toyota Kijang Innova di Semarang” Universitas Negeri Yogyakarta.

Goenadhi (2011) "Faktor-Faktor yang Mempengaruhi Perilaku Konsumen Dalam Program Studi Manajemen Fakultas Ekonomi Universitas Sebelas Maret Solo.

Kotler, Phillip. 2002. Manajemen Pemasaran Jilid II (edisi Bahasa Indonesia).

Jakarta: PT Prenhalindo Indonesia.

Kotler, Phillip.2005. Manajemen Pemasaran. Jilid 1. Jakarta: PT Indeks Kelompok Gramedia. Kotler, Philip dan Kevin Keller. 2009. Manajemen Pemasaran. Jilid 1. Edisi ke 13. Diterjemahkan oleh Bob Sabran. Jakarta: Erlangga.

Setiadi, Nugroho J. 2003. Perilaku Konsumen: Konsep dan Implikasi untuk Strategi dan Penelitian Pemasaran. Jakarta: Prenada Media.

Schiffman, Leon dan Leslie L. Kanuk. 2008. Perilaku Konsumen Edisi Ketujuh. Diterjemahkan oleh: Zoelkifli Kasip. Jakarta: Indeks.

Sutisna. 2003. Perilaku Konsumen dan Komunikasi Pemasaran. Bandung: PT.RemajaRosdakarya.

Sutisna dan Pawitra. 2001. Perilaku Konsumen dan Komunikasi Pemasaran. Jakarta : PT. Remaja Rosdakarya.

Philip Kotler \& Gary Armstrong. 2008. Manajemen Pemasaran. (Edisi terjemahan oleh Bob Sabran). Jakarta: Erlangga. 2008. 